\title{
INTERVENSI MULLIGAN MOBILIZATION WITH MOVEMENTLEBIH BAIK DARISEMISQUAT EXERCISEDALAM MENINGKATKAN FUNGSIONAL SENDI LUTUT PADA KASUS CHONDROMALACIA PATELLA
}

\author{
Maksimus Bisa \\ maxi.lado@yahoo.com \\ Prodi Fisioterapi Fakultas Vokasi \\ Universitas Kristen Indonesia \\ Jakarta, Indonesia
}

\begin{abstract}
This study is to determine the difference in intervention of mulligan mobilization with movement with anemia in exercise to improve the functional knee joint in the case of chondromalacia patella. This research was conducted at the Sukmajaya Physio Clinic in East Depok from April to July 2018. Methods: This study was quasi-experimental with a comparative approach to pre and post test group control design with a sample of 30 people, where sampling was done with allocation random sampling that met the inclusion criteria. Samples were grouped into two groups, namely treatment group I consisting of 15 people given intervention mulligan mobilization with movement and ultra sound and treatment group II consisting of 15 people given semisquat exercise dan ultra sound. Data analysis: using statistical tests. The results of the normality and homogeneity test of the two groups showed normal distribution and homogeneous data with a value of $\rho>$ 0.05 . The research hypothesis test was conducted by independent simple $t$ test comparative test using the difference between lower extremity functional scale (LEFS) and test stand between the treatment groups with treatment group II after intervention, it got $\rho=0.023$. Results: There were significant differences in the combination intervention of Mulligan Mobilization With Movement and ultrasound with a combination of Semi-squat exercise and ultrasound on functional improvement of the knee in the case of chondromalacia patella.
\end{abstract}

Keywords: mulligan mobilization, squat exercise, and chondromalacia patella.

ABSTRAK
Penelitian ini bertijuan untuk mengetahui perbedaan intervensi mulligan
mobilization with movementdengansemisquat exercisedalam meningkatkan 
fungsional sendi lutut pada kasus chondromalacia patella. Penelitian ini dilaksanakan di Klinik Fisio Sukmajaya Depok Timur bulan April hingga Juli 2018. Metode: penelitian ini bersifat quasi experimental dengan pendekatan komparatif pre dan post test group control design dengan jumlah sampel 30 orang, dimana pengambilan sampel dilakukan dengan allocationrandom sampling yang memenuhi kriteria inklusi. Sampel dikelompokkan menjadi dua kelompok yaitu kelompok perlakuan I terdiri dari 15 orang diberikan intervensi mulligan mobilization with movementdan ultra sounddan kelompok perlakuan II terdiri dari 15 orang diberikan semisquat exercisedan ultra sound. Analisis data: menggunakan uji statistik. Hasil uji normalitas dan homogenitas kedua kelompok menunjukkan data berdistribusi normal dan homogendengan nilai $\rho>0,05$. Uji hipotesis penelitian dilakukan dengan uji komparasi independent simple t-testmenggunakan data selisih nilai lower extremity functional scale (LEFS)dan strok blance stand testantara kelompok perlakuan I dengan kelompok perlakuan II sesudah intervensididapatkan $\rho=$ 0,023 . Hasil penelitian:ada perbedaan yang signifikan intervensi kombinasi Mulligan Mobilization With Movement dan ultrasound dengan kombinasi Semi squat exercise dan ultrasound terhadap peningkatan fungsional lutut pada kasus chondromalacia patella.

Kata kunci: mulligan mobilization, squat exercise, dan chondromalacia patella.

\section{PENDAHULUAN}

Lutut adalah sendi penumpu berat badan yang cenderung mengalami cidera. Hal ini disebabkan oleh beban berlebihan, Q-angel dari gerakan, dan perubahan degeneratif (Hatice Resorlu et al, 2016). Nyeri lutut merupakan keluhan pasien yang paling sering dijumpai. Penyebab nyeri lutut yang sering terjadi pada remaja dan dewasa muda adalah trauma seperti terjatuh, keseleo, atau naik turun tangga. Gangguan/kelainan yang sering terjadi adalah chondromalacia patella, yaitukondisi patologi pada tulang rawan (Fernandoet al, 2014).

Chondromalacia patella merupakan peradangan dan pelunakan tulang rawan pada bagian bawah patela. Pada umumnya patela bergerak meluncur secara halus tetapi pada kasus ini terjadi pergesekan antara 
Bisa, Intervensi Mulligan Mobilization with Movementlebih Baik dari semisquat Exercise dalam Meningkatkan Fungsional Sendi Lutut pada Kasus Chondromalacia Patella

patela dan femur (tulang paha). Chondromalacia patella disebabkan oleh banyak faktor diantaranya patella alta (mal alignment patella) yaitu posisi patela yang lebih tinggi dari lutut, kelemahan otot vastus medialis oblique, ketegangan pada lateral retinakulum dan beban mekanik. Kondisi ini mempengaruhi sendi lutut terutama sendi patellofemoral yang berdampak padamal aligment dari tempurung lutut, $Q$-angel meningkat, menegangnya lateral retinaculum patella, dan terjadi hypoplasia pada kondilus femoral. Selain itu terjadi penurunan kerja otot abduktor hip, kekuatan otot ekstensor hip menurun, dan peningkatan rotasi internal pada os femur sehingga terjadi posisi valgus pada lutut (Baczkowiczand dan majorczyk, 2016).

Problematik klinis yang sering ditemui pada kondisi chondromalacia patella adalah nyeri disekitar lutut (biasanya terletak dibelakang patela), nyeri timbul ketika diberikan beban dan adanya krepitasi. Hal ini menyebabkan pasien kesulitan melakukan aktifitas sehari-hari seperti naik turun tangga, jongkok, berlari, melompat, dan berolahraga. Dengan demikian chondromalacia patella merupakan suatu patologi yang kompleks, mengakibatkan seseorang kesulitan dalam melakukan aktivitas sehari-hari dan perlu dilakukan penanganan secara tepat agar dapat mengembalikan gerak fungsional tanpa keluhan nyeri.

Upaya penanganan fisioterapis untuk mengurangi ketidakmampuan dalam melakukan aktifitas yang diakibatkan oleh chondromalacia patella, diantaranya dengan metode elektroterapi, manual terapi, dan terapi latihan. Teknik manual terapi dalam penanganan chondromalacia patella berupa penerapan Muligan Mobilization with Movement (MWM), terapi latihan berupasemi squat exercise 
dan elektroterapi berupa ultrasound (US).

Muligan Mobilization with Movement adalah suatu teknik mobilisasi yang dipadukan dengan gerak fisiologis aktif pada akhir lingkup gerak sendi pasien (Kisner and Colby, 2012). MWM secara manual melibatkan pergerakan sendi yang dilakukan pasien secara aktif dan gerakan glide yang dikontrol oleh terapis. Teknik ini dilakukan secara bersamaan antara pasien dan terapis, pemberian teknik ini tidak boleh adanya rasa nyeri.

Semi squat exercise merupakan latihan yang bersifat closed kinetik chain exercise. Latihan ini dapat menguatkan otot ekstremitas bawah dengan meminimalkan stress (ketegangan) pada ligamen anterior dengan mengurangi gaya geser pada sendi lutut melalui pengurangan gaya tekan pada saat kontraksi (Lee et al, 2016). Latihan ini bertujuan untuk menjaga kestabilan patela dengan mengoptimalkan kinerja otot stabilisator.

Untuk menemukan gangguan gerak dan fungsi pada chondromalacia patella, maka fisioterapis perlu menganalisa secara menyeluruh melalui penatalaksanaan fisioterapi yang meliputi anamnesis, inspeksi, quick test, serta test khusus yang disertai dengan pemeriksaan penunjang yang dilakukan dengan algoritma dan berdasarkan evidence base practice. Didalam anamnesis, pasien dengan kondisi chondromalacia patella umumnya mengeluh nyeri dan mengalami gangguan fungsional pada daerah sekitar lutut yang terlokalisir pada sendi petellofemoral ketika melakukan aktivitas naik dan turun tangga. Kemudian pada saat gerak pasif fleksi ekstensi timbul nyeri dan krepitasi. Setelah itu dilanjutkan dengan test khusus diantaranya patellar apprehension test dan waldron test.

Penilaian dan evaluasi fungsi hasil intervensi, dapat dilakukan 
Bisa, Intervensi Mulligan Mobilization with Movementlebih Baik dari semisquat Exercise dalam Meningkatkan Fungsional Sendi Lutut pada Kasus Chondromalacia Patella

pengukuran terhadap peningkatan fungsional dengan lower extremity functional scale (LEFS) dan stork balance stand test. LEFS merupakan kuisioner yang berisi 20 item penilaian fungsional dengan tingkat kesulitan fungsional dari 0 (sangat sulit) sampai 4 (tidak ada kesulitan), menghasilkan skor maksimum 80 poin dimana skor yang lebih tinggi menunjukkan fungsi lebih baik (Fukuda, et al 2012). Stork balance stand test mempunyai tabel skor penilaian yang dihitung dalam detik, dengan kriteria sangat bagus, bagus, ratarata, cukup, dan buruk. (Jhonson dan Nelson, 1979).

\section{TINJAUAN TEORITIS}

Penurunan fungsional lutut pada chondromalacia patella terjadi karena adanya kondisi dimana tulang rawan pada tempurung lutut mengalami kerusakan. Di permukaan bawah tempurung lutut yang sehat terdapat tulang rawan artikular yang halus dan licin, permukaan ini memungkinkan tempurung lutut meluncur dialurnya dengan mudah ketika menekuk atau meluruskan lutut. Ketika terjadi chondromalacia patella permukaan bawah tempurung lutut menjadi kasar dan menipis yang disebabkan karena adanya tekanan yang terjadi secara berulang-ulang pada tulang rawan di bagian patellofemoral sehingga menyebabkan terjadinya peradangan, pelembekan dan pengelupasan pada tulang rawan serta menyebabkan timbulnya nyeri pada bagian anterior patella. Cidera yang terjadi akan menyebabkan erosi pada permukaan tulang rawan sendi yang diikuti dengan penebalan tulang subkondral sehingga timbul osteofit dan menyebabkan iritasi jaringan. Chondromalacia patella merupakan kondisi dimana tulang rawan pada tempurung lutut mengalami kerusakan karena kondisi lutut valgus atau varus yang menyebabkan otot vastus medialis oblique, otot vastus lateralis dan otot pes anserinus 
melemah sehingga menyebabkan mal aligment gerak patella, deformitas lutut, dan nyeri bagian anterior patella.

\section{Anatomi dan Biomekanik Sendi} Lutut

Sendi lutut dirancang untung mobilitas dan stabilitas, secara fungsional bekerja untuk memperpanjang dan memperpendek ekstremitas bawah untuk menaikkan atau menurunkan tubuh dan memberi ruang gerak pada kaki (Kisner and Colby, 2012). Secara anatomi sendi lutut adalah sendi terbesar dalam tubuh manusia. Sendi lutut terdiri dari sendi tibiofemoral, sendi patellofemoral, dan sendi proximal tibiofibular. Sendi lutut termasuk jenis synovial hinge joint dengan gerakan fleksi dan ekstensi. Fungsi sendi lutut ini untuk menopang tubuh, penumpu berat badan, pembentuk sikap, dan berfungsi seperti menendang. Karena struktur dan fungsinya yang kompleks, maka sendi lutut memiliki susunan anatomi dan biomekanik yang berbeda, sesuai dengan bentuk dan struktur pembentuknya.

Sendi lutut dibentuk oleh bagian distal tulang femur, patella dan bagian proximal tulang tibia. Pada bagian distal tulang femur dibentuk oleh condylus medialis dan condylus lateralis. Apabila dilihat dari permukaan sendinya nampak bahwa permukaan sendi dari tulang femur dan tibia tidak terdapat kesesuaian bentuk. Kedua condylus femur lateral dan medial membentuk katrol, sedang permukaan tibia diantaranya lebih rata. Condylus femoralis melebar kearah distal dan posterior, condylus lateralis lebih lebar di bagian depan daripada belakang, sedangkan condylus medialis tebalnya tidak berubah. Pada bagian ventral membentuk facies yang bersendi dengan patella dan tibia. Patella merupakan tulang sesamoid terbesar pada tubuh manusia, berfungsi untuk meningkatkan efisiensi fleksi dan 
Bisa, Intervensi Mulligan Mobilization with Movementlebih Baik dari semisquat Exercise dalam Meningkatkan Fungsional Sendi Lutut pada Kasus Chondromalacia Patella

melindungi sendi yang ada pada lutut (Waryasz dan McDemort, 2008). Patella dilapisi oleh kartilago sendi atau tulang rawan sendi.

Kartilago merupakan tulang rawan hialin yang bewarna putih kebiru-biruan, yang terdiri dari kondrosit (sel rawan sendi) dan matrix ekstraseluler. Kondrosit berfungsi mensistesis dan memelihara matrix rawan sehingga fungsi bantalan rawan sendi tetap terjaga dengan baik. Matrix ekstraseluer subtansi dasarnya terdiri dari $65 \%-80 \%$ air $15 \%-25 \%$ kolagen dan $10 \%$ proteoglikan (Corwin elizabeth, 2007). Kartilagoberfungsi untuk mencegah terjadinya gesekan pada permukaan sendi dan sebagai peredam guncangan. Kartilagotidak memiliki jaringan saraf dan sedikit pembuluh darah,memperoleh makanannya melalui difusi dari kapiler melalui jaringan ikat yang berdekatan (perikondrium) atau melalui cairan synovial.
Bagian proximal tulang tibia terdapat condylus medialis dan lateralis. Permukaan proximal fasies articularis superior terpisah oleh eminensia intercondylaris. Eminensia intercondylaris ini sebagai perlekatan ligamentum cruciatum yang sering dijumpai osteofit.

Sendi lutut dibentuk oleh beberapa ligament yang berfungsi memberikan stabilisasi sendi lutut antara lain ligament cruciatum, dimana ligament cruciatum anterior membentang dari bagian anterior tibia, melekat pada bagian lateral condylus lateralis femur yang berfungsi untuk mencegah gerakan anterior tibia diatas femur. Menahan eksorotasi tibia pada saat fleksi lutut, mencegah hiperekstensi lutut dan membantu saat gliding (meluncur) dan rolling (menggelending) sendi lutut. Sedangkan ligament cruciatum posterior merupakan ligament terkuat pada sendi lutut yang berbentuk kipas, membentang dari bagian posterior tibia ke bagian 
depan atas dan melekat pada condylus medialis femur. Ligament ini berfungsi untuk memelihara stabilitas dan mencegah hiperekstensi sendi lutut.

Ligament collateral medial lebih posterior di permukaan sendi tibiofemoral. Seluruh ligament collateral medial menegang pada gerakan ekstensi penuh lutut. Ligament collateral lateral membentang dari permukaan luar condylus lateralis femoris kearah caput fibula, dalam gerakan fleksi lutut ligament ini melindungi sisi lateral sendi lutut. Antara condylus femoralis dan condylus tibia dilapisi oleh meniscus dengan struktur fibro cartilage yang melekat pada kapsul sendi.

Patellofemoral ligament merupakan ligamen yang memberikan stabilisasi patella, dimana ligament ini berasal dari bagian tengah trochlear lalu memutar ke bagian depan femur. ligament patellofemoral medial berperan dalam gerakan ekstensi lutut. Selain ligament sendi lutut juga distabilisasi oleh kapsul sendi yang terdiri dari dua lapisan yaitu stratum fibrosum yang merupakan lapisan luar yang berfungsi sebagi selubung dan stratum synovial merupakan lapisan dalam yang berfungsi memproduksi cairan synovial untuk melicinkan permukaan sendi.

Otot ekstensor lutut adalah otot quadriceps femoris yang berfungsi untuk gerakan ekstensi lutut.Otot ini selain sebagai penggerak juga berfungsi sebagai stabilitas lutut ketika posisi tubuh berdiri. Grup otot ini terdiri dari 4 otot yaitu m.rectus femoris, m.vastus medialis, m.vastus intermeidus dan m.vastus lateralis. Selain mempunyai fungsi utama sebagai gerakan ekstensi lutut keempat otot ini mempunyai fungsi lainnya masing-masing. m.rectus femoris berperan dalam fleksi hip, $m$. vastus medialis membantu otototot pes anserinus dalam menjaga stabilitas medial lutut dan berfungsi membuat gerakan rotasi internal pada patella, $m$. vastus lateralis 
Bisa, Intervensi Mulligan Mobilization with Movementlebih Baik dari semisquat Exercise dalam Meningkatkan Fungsional Sendi Lutut pada Kasus Chondromalacia Patella

membantu otot illiotibial dalam mempertahankan stabilitas sendi sisi lateral dan membuat gerak rotasi eksternal pada patella. Keempat otot ini berinsertio pada tempat yang sama yaitu, kearah patella dan berlanjut hingga menuju tuberculum tibia. Mekanisme kerja quadriceps ini dibutuhkan seperti saat berjalan otot quadriceps memberi kontrol fleksi lutut saat initial contact (loading respons) kemudian ekstensi lutut untuk midstance kemudian preswing heel-off to toe off pada aktifitas berjalan dan dalam mempertahankan fungsi sendi lutut saat melakukan gerakan closed-kinetic chain untuk mengangkat atau menurunkan beban tubuh, dan jika fungsi otot quadriceps terganggu tentu control gerak tersebut tidak dapat dilakukan dengan benar (Kisner dan Colby, 2012).

Otot hamstring merupakan fleksor lutut premier dan juga mempengaruhi rotasi tibiapada femur. Karena mereka adalah two- joint muscles, mereka berkontraksi lebih efisien ketika mereka bersamaan diperpanjang atas hip (selama hip fleksi) seperti mereka memfleksikan lutut. Selama closed chain activities otot hamstring dapat membantu mengekstensikan lutut dengan menarik tibia. Otot hamstring juga berfungsi sebagai stabilisator ketika ada gaya berlebih kearah depan, guna membantu fungsi dari anterior crusiatum ligament. Otot hamstring terdiri dari tiga otot yaitu, m.semitendinosus,

m.semimmembranosus, dan m.biceps femoris. Dalam perannya pada lutut, otot hamstring dibantu oleh m.gastrocnemius untuk mempertahankan stabilitas pada bagian posterior. Otot semitendinosus berfungsi untuk ekstensi hip dan fleksi lutut. Otot ini dipersarafi oleh N. Ischiadicus (L5S2). Ototsemitendinosus bersamasama dengan m.gracilis dan m.sartorius membentuk gabungan yang disebut dengan pes anserinus. Pes anserinus ini 
berperan penting dalam menjaga stabilitas lutut sisi medial karena menahan gaya kearah medial posterior lutut. Otot semimembranosus berfungsi untuk ekstensi hip dan fleksi lutut. Dipersarafi oleh $N$. Ischiadicum (L5-S2). Otot biceps femoris berfungsi untuk ekstensi hip dan fleksi lutut. Dipersarafi oleh $N$. Ischiadicus (L5-S2). Otot hamstring mengatur ayunan kaki kedepan selama terminal swing, hamstring juga memberi support pada posterior sendi lutut ketika lutut ekstensi selama stancephase. Kelemahan otot hamstring dapat menimbulkan genu recurvatum (Kisner and Colby, 2012).

Kelompok otot pes anserinus merupakan otot penting untuk stabilitasi aktif lutut bagian medial. Otot ini membentang sejauh facies medialis tibiae yang berinsersio bersama-sama dengan m.semitendinosus dan m.sartorius sebagai pes anserinus. Otot ini terletak paling medial, langsung dibawah permukaan medial sendi lutut dan bila paha diabduksikan tampak jelas gambaran lengkungannya. Otot ini berfungsi sebagai adductor sendipanggul dan bila lutut difleksikan otot anserinus ini bersama-sama otot lain berfungsi sebagai rotator medial tungkai bawah dan juga penting mempertahankan secara aktif agar tidak terjadi genu valgus. Secara umum dapat dilihat pada gambar 1. 
Bisa, Intervensi Mulligan Mobilization with Movementlebih Baik dari semisquat Exercise dalam Meningkatkan Fungsional Sendi Lutut pada Kasus Chondromalacia Patella

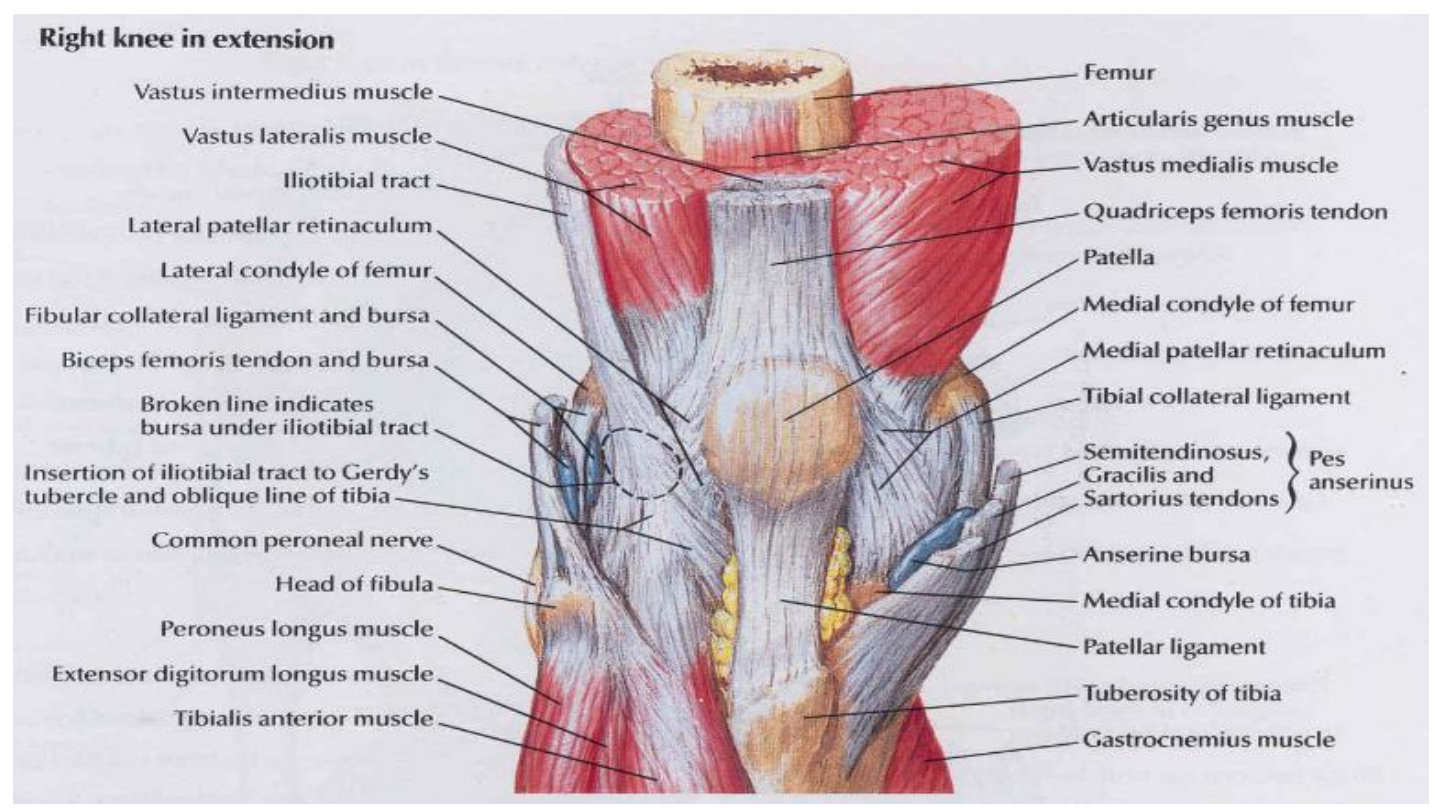

Gambar 1. Otot Pes Anserinus (F.Netter, 2006)

Pada sendi terjadi dua macam gerakan yaitu gerak osteokinematik dan arthrokinematik.

Gerakosteokinematik merupakan gerakan yang terjadi pada tulangtulang pembentuk sendidan merupakan gerakan fisiologis sendi. Lutut merupakan hinge joint dengan gerak rotasi ayun dalam bidang sagital dan menghasilkan gerakan fleksi dengan nilai LGS normal $130^{\circ}-140^{\circ}$ dengansoft end feel, posisi hiperekstensi berkisar antara $5^{\circ}-10^{\circ}$ dalam batas normalnya dengan hard end feel. Selain rotasi swing/ayun, lutut juga mempunyai gerak rotasi spin dalam bidang transversal pada posisi lutut fleksi dan menghasilkan gerakan internal rotasi $15^{\circ}-30^{\circ}$ dengan elastic end feel dan eksternal rotasi $40^{\circ}-45^{\circ}$ pada posisi awal, mid posisi dengan elastic end feel, pada gerak akhir ekstensi terjadi eksternal rotasi yang dikenal sebagai closed rotation (Sugijanto, 2008). Pada kedua permukaan sendi lutut, gerakan yang terjadi meliputi gerak sliding dan rolling, maka disinilah berlaku hukum concave-convex. Hukum ini menyatakan bahwa "jika permukaan sendi cembung 
(convex) bergerak pada Sedangkan saat ekstensi akan permukaan sendi cekung (concave) maka pergerakan sliding dan rolling searah". Gerak arthrokinematik merupakan gerakan pada permukaan sendi. Gerak arthrokinematik dari lutut yaitu traksi dan kompresi dengan arah kaudal-kranial searah axis longitudinal. Gerak translasi ke dorsal dan ke medial terjadi saat fleksi sedangkan translasi ke ventral dan ke lateral terjadi saat gerak ekstensi. Kondilus tibiofemoral yang tidak simetris dari permukaan sendi tibia menunjukkan bahwa ketika kondilus femur bergerak pada kondilus tibia (dengan kondisi menumpu berat badan), kondilus femur harus roll dan slide terhadap kondilus tibia. Pada saat gerakan fleksi, terjadi flexion lock mechanism sehingga akan terjadi rotasi medial (varus), yaitu kondilus femur roll ke posterior dan slide ke anterior. Meniskus pada sendi lutut mengikuti roll dari kondilus dengan bergerak ke posterior saat fleksi.

\section{Epidemiologi, Etiologi, dan Patofisiologi}

\section{Epidemiologi}

Patellofemoral pain syndrome (PFPS) lebih banyak dialami wanita, $13-18 \%$ permasalahan lutut terjadi pada wanita di usia 18-35 tahun (Zemadanis et al, 
Bisa, Intervensi Mulligan Mobilization with Movementlebih Baik dari semisquat Exercise dalam Meningkatkan Fungsional Sendi Lutut pada Kasus Chondromalacia Patella

2015). Kasus chondromalacia patella memiliki tingkat prevalensi $36,2 \%$. Jumlah penderita wanita lebih banyak dibandingkan pria (Du Jie, Zhang Jin, 2010).

\section{Etiologi}

a. Jenis kelamin

Penderita patella femoral pain syndrome lebih banyak terjadi pada wanita dibanding dengan pria (Lankhorst et al, 2012). Dalam hal ini wanita cendrung lebih aktif dibanding pria karena wanita banyak melakukan aktivitas berulang dan berat.

b. Beban mekanik

Tempurung lutut menerima beban kompresi yang berbeda beda pada setiap kegiatan. Besar tekanan pada tempurung lutut semakin meningkat seiring garis vektor pada fleksi lutut. Pada fleksi lutut otot quadriceps dan patellar ligament bersama-sama menarik tempurung lutut ke sumbunya sehingga patella akan tertekan. Ketika akan melakukan suatu aksi, besar beban yang dikeluarkan melalui lutut secara tegak lurus kebawah akan mendapatkan tambahan gaya berupa gravity force, besarnya gaya yang dikeluarkan tersebut akan sebanding dengan reaksi yang diterima lutut. Pada sistematik review ditemukan bahwa secara umum chondromalacia patella menunjukkan nyeri diarea tempurung lutut dalam hubungannya dengan aktivitas yang memberi beban pada sendi patellofemoral (Crossley et al, 2001).

c. Mal aligment

Garis tegak lurus (alignment) anggota gerak 


$\begin{array}{ll}\text { bawah sangat } & \text { Dalam waktu yang lama } \\ \text { mempengaruhi dari } & \text { maltracking pada } \\ \text { problem chondromalacia } & \text { tempurung lutut ini akan } \\ \text { patella. Quadriceps angel } & \text { menyebabkan microtrauma } \\ \text { (Q angel) merupakan sudut } & \text { pada tulang rawan dibagian } \\ \text { yang dilihat dengan } & \text { belakang tempurung lutut } \\ \text { menarik garis maya lurus } & \text { dan mengakibatkan rasa } \\ \text { dari anterior super iliac } & \text { sakit yang dikenal sebagai } \\ \text { spine (ASIS) ke titik tengah } & \text { nyeri lutut anterior, nyeri } \\ \text { dari tulang patella dan dari } & \text { sendi patellofemoral atau } \\ \text { titik tengah patella ke } & \text { chondromalacia patella } \\ \text { tuberositas tibia (Jaiyesimi } & \text { (Waryaszet, 2008). } \\ \text { et al, 2009). Semakin tinggi } & \text { d. Genu valgus } \\ \text { nilai sudut q-angel maka } & \text { Genu valgus merupakan } \\ \text { semakin besar pula tarikan } & \text { abnormalitas sudut } q \text {-angel } \\ \text { pada otot quadriceps } & \text { yang melebihi sudut } \\ \text { femoris kearah lateral dan } & \text { normal, dikatakan genu } \\ \text { menjadi faktor terjadinya } & \text { valgus apabila sudut q- } \\ \text { maltracking patella pada } & \text { angel >18 pada wanita } \\ \text { alurnya yang berpotensi } & \text { dan }>12^{\circ} \text { pada pria. Pada } \\ \text { terjadinya gangguan pada } & \text { kondisi yang parah kedua } \\ \text { sindroma nyeri } & \text { tempurung lutut dapat } \\ \text { patellofemoral, } & \text { saling bersentuhan atau } \\ \text { chondromalacia patella, } & \text { biasa disebut knock knee. } \\ \text { dan subluxasi patella } & \text { Secara biomekanik, pada } \\ \text { lateralis berulang. Stabilitas } & \text { genu valgus akan terjadi } \\ \text { pada tempurung lutut } & \text { pergeseran tempurung lutut } \\ \text { dipengaruhi oleh kontraksi } & \text { dan alur geraknya ke sisi } \\ \text { otot quadriceps femoris. } & \text { lateral mengikuti vector }\end{array}$


Bisa, Intervensi Mulligan Mobilization with Movementlebih Baik dari semisquat Exercise dalam Meningkatkan Fungsional Sendi Lutut pada Kasus Chondromalacia Patella

valgus. Stabilisasi jaringan lunak lateral dan medial menajadi tidak stabil, vastus medial dan medial retinaculum serta ligament collateral medial meregang sehingga stabilisasi medial lemah, sedangkan vastus lateral, lateral retinaculum, ligament collateral lateral serta illiotibialband menegang sehingga akan menarik tempurung lutut ke lateral bergeser dari akurnya. Karena tempurung lutut tidak bergerak di alur yang benar sehingga gesekannya akan menimbulkan

suatu kerusakan jaringan permukaan periosteum dan cartilage sisi lateral sampai permukaan subchondral, erosi cartilage menyebabkan gesekan antar tulang sehingga iritasi dan nyeri (Rodigues, 2008).

e. Genu Varus
Lutut dikatan genu varus ketika lutut memiliki sudut $q$-angel $<0^{\circ}$ sehingga lutut membentuk angulasi ke sisi medial atau biasa disebut dengan bow leg. Genu varus biasanya didapat karena suatu penyakit kongenital yang dibawa sejak lahir atau karena idiopatic.

Pada lutut varus yang terjadi adalah patella mengikuti arah angulasi ke sisi medial, otot vastus medialis, medial retinaculum dan ligament collateral medial menarik patella ke medial, sementara stabilitas lateral oleh vastus lateralis, lateral retinaculum dan ligament collateral lateral melemah.

Perubahan aligment patella ke sisi medial ini memaksa patella terus bergerak dengan throclear sisi medial yang tidak sesuai untuk alur gerak patella 
sehingga akan merusak jaringan sisi medial (Rodrigues, 2008).

f. Kelemahan otot vastus medialis Chondromalacia patella dihubungkan dengan adanya ketidakmampuan atau kelemahan dan imbalance otot quadriceps. Tendon otot vastus medialis tereletak pada sisi medial patella, otot ini bertindak sebagai salah satu sistem stabilisasi lutut sisi medial, ketika terjadi imbalance sistem stabilisasi lutut, maka akan terjadi mal aligment lutut. Kelemahan otot vastus medialis ditemukan pada seseorang yang memiliki sudut $q$ angel melebihi normal. Kelemahan ini memungkinkan patella bergeser ke lateral akibat stabilisasi lateral lebih kuat. Gesekan disatu sisi ini akan merusak jaringan lunak lutut sisi lateral.

\section{Patofisiologi}

Chondromalacia patella merupakan suatu kondisi dimana adanya gejala nyeri pada bagian anterior lutut dan keterbatasan fungsi lutut yang disebabkan oleh kerusakan dan perubahan bentuks tulang rawan juga jaringan lain disekitar periosteum, subchondral, dan permukaan tulang. Hal ini terjadi karena adanya perubahan alur gerak patella terhadap troclear femur oleh karena kelemahan otot vastus medialis dan atau karena adanya genu valgus. Sehingga gerakan tersebut menyebabkan sisi tulang rawan menajadi tipis dan erosi sampai ke permukkan subchondra, periousteum patella dan trochlear femur robek dan rusak sampai permukaan tulang, gesekan antar tulang menyebabkan kerusakan permukaan tulang 
Bisa, Intervensi Mulligan Mobilization with Movementlebih Baik dari semisquat Exercise dalam Meningkatkan Fungsional Sendi Lutut pada Kasus Chondromalacia Patella

sehingga menjadi kasar dan timbul nyeri.

\section{a. Body structure impairment} Chondromalacia patella adalah patologi kerusakan pada cartilage sendi patellofemoral, yang disebabkan karena ketidak seimbangan sistem jaringan lunak yang membentuk stabilitas lutut, akibatnya gesekan terus menerus akan menggerus cartilage hingga menipis dan akhirnya mengelupas dan membuka permukaan subchondral dan tulang. Ketika terjadi gesekan atau penekanan pada permukaan sendi maka benturan akan menghantam permukaan tulang sehingga mengiritasi ujung saraf yang terdapat pada tulang tersebut. Kerusakan cartilage menyebabkan matrix cartilage rusak, pembentukan dan difusi protein terganggu sehingga terjadi kematian cartilage di area injury. Cartilage sangat berpengaruh terhadap fungsinya pada sendi patellofemoral sebagai peredam tekanan dan gerusan serta pelicin dan pengarah gerak. Maka fungsi tersebut juga akan mengalami penurunan. Kerusakan juga terjadi pada lapisan periosteum, dimana gesekan dan tekanan terus menerus akan mengiritasi dan merobek periosteum, sehingga fungsi periosteum sebagai pelindung tulang akan terkelupas, kemudian gesekannya mengenai permukaan tulang sehingga permukaan tulang menjadi kasar dan rusak.

Kerusakan pada periosteum tersebut akan membentuk suatu jaringan fibrous baru, pada subchondral dan pada 
tulang akan muncul osteofit baru, dan terbentuk cartilage baru yang akan menggantikan cartilage yang rusak. Pembentukkan osteofit baru yang tajam jika saling berbenturan juga dapat mengiritasi dan menimbulkan nyeri. Penumpukan fibrous pada peiosteum akan membentuk abnormal crosslink, osteofit tulang, dan subchondral akan menebal sehingga kekuatan tumpu dan absorbsi tumpuan menurun.

Struktur impairment diatas semakin menggangu gerak patella terhadap trochlear femur, gerakan menjadi kasar dan tidak licin serta terbatas. Impairment nyeri juga menyebabkan inefisiensi kerja dari otot quadriceps, sehingga orang akan merasakan kelemahan

ketika melakukan suatu pekerjaan.

b. Body Functional impairment Seseorang akan kesulitan dalam aktivitas fungsional ekstremitas bawah seperti squat (ICF code d4151) karena inefisiensi kerja otot quadriceps terutama kelemahan otot vastus medialis, juga karena nyeri akibat kontraksi otot secara eksentrik yang menarik patella ke atas dan oleh tendon patellaris patella ditarik ke bawah sehingga menekan patella. Aktivitas melompat (ICF code d4553) juga sulit dilakukan karena awalan melompat dibutuhkan posisi squat dimana posisi ini terasa berat karena mengiritasi dan menyebabkan nyeri ditambah dengan akhiran lompatan mendapatkan tekanan gravitasi seta beban tubuh sehingga 
Bisa, Intervensi Mulligan Mobilization with Movementlebih Baik dari semisquat Exercise dalam Meningkatkan Fungsional Sendi Lutut pada Kasus Chondromalacia Patella

terjadi kompresi pada sendi patellofemoral. Aktivitas naik turun tangga (ICF code d4551) lebih berat dikerjakan karena pada prinsipnya menumpu berat tubuh pada satu kaki secara bergantian, lutut mendapat beban tubuh saat pijakan kaki dari posisi fleksi ke ekstensi untuk manaiki tangga, dan otot quadriceps harus berkontraksi kuat untuk menopang berat tubuh tersebut sehingga permukaan sendi patellofemoral mendapatkan tekanan dan gerusan yang semakin mengiritasi dan menambah rasa nyeri.Aktivitas lainnya seperti berjalan jauh (ICF code d4501) dan berlari (ICF code d4552) keduanya merupakan gerakan kontinyu sehingga gesekan dan tekanan semakin kuat dan menimbulkan jalan pincang (ICF code b770).

\section{Lower Extremity Functional} Scale (LEFS)

Lower Extremity Functional Scale (LEFS) merupakan kuesioner berisi 20 pertanyaan mengenai kemampuan seseorang dalam melakukan aktifitas fungsional. LEFS dapat digunakan untuk mengevaluasi gangguan fungsional ekstremitas bawah dan memantau efektivitas intervensi yang diberikan kepada pasien (Binkley JM et al, 1999). Intruksi penilaian fungsional ada pada kolom skala, kemudian dijumlahkan untuk mendapatkan skor total. Skor maksimum adalah 80, dan semakin rendah skor maka semakin besar kecacatan. Dengan perhitungan $\%$ fungsional maksimal $=($ LEFS $) / 80 \times 100$. Minimal peningkatan skor adalah 9 poin.

Instruksi : kami tertarik untuk mengetahui apakah anda mengalami kesulitan dengan 
aktivitas fungsional seperti yang tercantum dibawah ini yang dikarenakan masalah pada ekstremitas bawah anda. Mohon berikan jawaban yang sesuai untuk setiap aktivitas tersebut. Hari ini, apakah anda mengalami kesulitan dengan aktivitas fungsional tersebut?

Table 1 Penilaian :

\begin{tabular}{lll}
\hline Sangat sulit (tidak dapat melakukan aktivitas) & & 0 \\
Sulit & 1 & \\
Cukup sulit & 2 \\
Sedikit sulit & 3 & 4 \\
Tidak sulit & \\
Nilai skor total & $0-80$ \\
\hline
\end{tabular}

Binkley JM et al, 1999

Nilai yang lebih tinggi menunjukkan kemampuan aktivitas fungsional ekstremitas bawah yang semakin baik.

Prosedur pengukuran :

1. Beri penjelasan kepada pasien mengenai isi dan cara mengisi kuisioner LEFS. Kuisioner berisi 20 pertanyaan mengenai kemampuan seseorang untuk melakukan tugas fungsional.
2. Untuk pengisian kuisioner, pasien dipandu oleh fisioterapis melakukan tugas tersebut sehingga menjadi akurat.

3. Hasil dari tugas fungsional mendapat nilai 0-4, dimana 0 berarti sangat sulit atau tidak dapat melakukan aktivitas, sedangkan nilai 4 adalah tidak sulit atau mudah. Jumlah skor yang 
Bisa, Intervensi Mulligan Mobilization with Movementlebih Baik dari semisquat Exercise dalam Meningkatkan Fungsional Sendi Lutut pada Kasus Chondromalacia Patella

didapatkan akan dibagi 80 kemudian dikalikan $100 \%$.

\section{Stork Balance Stand Test}

Stork balance stand test bertujuan untuk menilai keseimbangan (Johnson BL and Nelson JK, 1979), dengan cara:

1. Lepaskan sepatu dan tanggan ditempatkan dipinggul sehingga tidak ada yang mendukung pergerakan kaki

2. Pasien diberikan waktu satu menit untuk berlatih
3. Pasien berdiri satu kaki dengan posisi tangan dipinggul diatas half balance wall.

4. Stopwatch dimulai ketika kaki pasien sudah diangkat dari lantai.

5. Stopwatch dihentikan apabila terjadi tangan turun dari pinggang, kaki memutar atau bergerak, kaki yang diatas lutut turun kebawah, dan kaki menyantuh lantai.

Table 2. Penilaian dihitung dari total waktu yang dicatat dalam detik.

\begin{tabular}{ll}
\hline Peringkat & Skor \\
\hline Excellent & $>50$ \\
Good & $40-50$ \\
Average & $25-39$ \\
Fair & $10-24$ \\
Poor & $<10$ \\
\hline
\end{tabular}

Johnson BL and Nelson, 1979

$\begin{array}{ccl}\begin{array}{l}\text { Mulligan Mobilization } \\ \text { Movement }\end{array} & \text { with } & \begin{array}{l}\text { mobilization with movement } \\ \text { (MWM) adalah kelanjutan alami }\end{array} \\ \text { Konsep } & \text { Brian } & \begin{array}{l}\text { dari evolusi manual terapi dari } \\ \text { Mulligant(1999) }\end{array} \\ \text { tentang } & \text { dasar-dasar latihan perbaikan }\end{array}$


dan latihan aktif dari praktisi diterapkan gerakan fisiologis pasif dan ke teknik aksesori mobilisasi pasif. Mobilisasi dengan gerakan fisiologis aktif atau pasif. Pasif akhir-range overpressure dapat diterapkan tanpa rasa sakit sebagai penghalang. Konsep Mulligan menggunakan mobilisasi sendi berupa teknik osilasi dan roll glide. Kedua teknik tersebut menggunakan gerak fisiologis atau gerak asesoris (Kisner and Colby, 2012). Penerapan konsep Mulligan tidak ada rasa sakit yang ditimbulkan selama dan setelah aplikasi dilakukan. Keberhasilan dari teknik ini ditandai dengan tidak ditemukan rasa nyeri selama fisioterapis melakukan teknik dalam menggerakkan dan meningkatkan fungsi. Patokan mulligan adalah mengendalikan dari posisi yang salah untuk dijadikan konsep, satu per satu mekanisme penelusuran gerak dan fungsi sendi dirotasikan dengan mempertimbangkan respon neurofisiologisnya (Mulligan, 1999).

Efek mekanikal yang dihasilkan oleh teknik mobilisasi adalah gerakan sendi dapat menstimulus aktivitas biologis oleh adanya gerakan cairan sinovial yang membawa nutrisi ke tulang rawan yang avaskular didalam permukaan sendi dan ke jaringan meniskus (fibrocartilago intra-artocular), gerakan sendi dapat memelihara ekstensibilitas dan kekuatan regangan dari jaringan sendi dan periartikular. Dengan efek mekanikal tersebut maka teknik mobilisasi dapat digunakan untuk mengobati kekakuan sendi (stiffness) atau hipomobilitas sendi, dimana dapat mengahasilkan peningkatan mobilitas kapsuloligamentair dan deformasi plastic serta menghasilkan stretching pada jaringan lunak yang memendek (Mulligan, 2001). 
Bisa, Intervensi Mulligan Mobilization with Movementlebih Baik dari semisquat Exercise dalam Meningkatkan Fungsional Sendi Lutut pada Kasus Chondromalacia Patella

\section{Semi Squat Exercise}

Semi squat exercise merupakan latihan yang bersifat closed kinetik chain exercise, latihan ini dapat menguatkan otot ekstremitas bawah dengan meminimalkan stres pada ligament anterior dengan mengurangi gaya geser pada sendi lutut melalui pengurangan gaya tekan pada saat kontraksi (Tae- Sik Lee et al, 2016).Semi squat exercise termasuk tipe latihan isotonik jenis eksentrik dimana kontraksi eksentrik terjadi dengan pemanjangan otot dengan tonus tetap. Kontraksi ini mengontrol gerakan dan menghasilkan force yang besar pada kecepatan tinggi. Kontraksi eksentrik adalah yang paling powerfull dibanding isometrik dan konsentrik.

Penambahan mini band diberikan pada saat latihan guna mengembalikan stabilitas sisi medial patella sehingga patella kembali ke posisi sebenarnya. Salah satu penyebab patologi chondromalacia patella adalah ketidakseimbangan kerja sistem jaringan lunak sekitar sendi patellofemoral, terutama kelemahan otot vastus medialis yang disebabkan oleh genu valgus maupun karena penyebab lain. Kelemahan otot vastus medialis memungkinkan medial retinaculum bekerja lebih berat untuk menjaga stabilitas lutut sisi medial. Sedangkan sisi lateral lutut yaitu vastus lateralis beserta lateral retinaculum menarik patella ke sisi lateral dan lama-kelamaan medial retinaculum akan terulur. Keadaan ini yang kemudian merubah aligment patella menjadi ke sisi lateral, padahal permukaan sisi lateral ini tidak sesuai dengan posisi patella terhadap trochlear femur, sehingga ketika gesekan yang terus-menerus akan merusak permukaan cartilage, dengan dimulainya kerusakan cartilage sendi patellofemoral inilah yang disebut chondromalacia patella.

Semi squat exercise diharapkan dapat menigkatkan kekuatan otot 
dan daya tahan otot quadriceps terutama otot vastus medialis, sehingga dapat mengembalikan fungsinya sebagai stabilisasi aktif sisi medial sendi patellofemoral. Kontraksi vastus medialis memperbaiki alur gerak patellalebih ke medial secara biomekanik sehingga benturan patella terhadap trochlear berkurang. Sistem stabilitas yang seimbang antara medial, lateral, proksimal dan distal akan mengembalikan patella keposisi yang benar pada trochlear femur. Ketika posisi patella kembali normal, maka gerakan patella akan lebih halus karena gesekan terjadi pada permukaan yang seharusnya. Pada sampel dengan genu varus diberikan mini band, sedangkan sampel genu valgus diberikan medicine ball untuk menjaga posisi patella.

\section{METODE PENELITIAN}

Penelitian ini bersifat quasi experimental untuk menguji dan mengetahui perbedaan antara pemberian intervensi Mulligan Mobilization With Movement dan ultrasound dengan Semi squat exercise dan ultrasound terhadap peningkatan fungsional lutut pada kasus chondromalacia patelladi Klinik Fisio Depok Jawa Barat. Desain penelitian yang digunakan adalah pre-test dan post-test grup desain. Penelitian ini dilakukan pada dua kelompok dengan jumlah sampel masing-masing kelompok sebesar 15 orang (Pocock, 2008). Kelompok perlakuan I yang diberikan intervensi Mulligan Mobilization With Movement dan ultrasound sedangkan kelompok perlakuan II diberikan intervensi semi squat exercise dan ultrasound. Alat ukur yang digunakan untuk menentukan hasil peningkatan fungsional lutut pada pasien chondromalacia patella adalah dengan Lower Extremity Functional Scale (LEFS) dan Stork Balance Stand Test. Sebelum diberikan intervensi, dilakukan pengukuran terlebih dahulu terhadap fungsional lutut 
Bisa, Intervensi Mulligan Mobilization with Movementlebih Baik dari semisquat Exercise dalam Meningkatkan Fungsional Sendi Lutut pada Kasus Chondromalacia Patella

menggunakan Lower Extremity Functional Scale (LEFS) dan Strok Balance Stand Test. Selanjutnya sampel diberikan intervensi sebanyak $9 x$ dengan frekuensi $3 x$ dalam satu minggu. Kemudian dilakukan pengukuran kembali sebagai bahan evaluasi di setiap minggunya, hal ini dilakukan untuk menentukan tingkat keberhasilan dari intervensi yang telah diberikan. Hasil dari perlakuan I dan II dianalisa dan dibandingkan antara kelompok perlakuan I dan kelompok perlakuan II sebelum dan sesudah intervensi.

\section{HASIL DAN PEMBAHASAN}

\section{A. Hasil Pengukuran Lower Extremity Functional Scale (LEFS)}

Table 3. Hasil pengukuran LEFS kelompok perlakuan I dan II

\begin{tabular}{|c|c|c|}
\hline & Kelompok perlakuan I & \multirow{2}{*}{ Kelompok perlakuan I } \\
\hline & Mean & \\
\hline Sebelum & $61,75 \pm 5,78$ & $61,16 \pm 7,85$ \\
\hline Sesudah & $79,83 \pm 4,32$ & $74,83 \pm 9,84$ \\
\hline
\end{tabular}

Pengukuran LEFS pada kelompok perlakuan I dan II dimana pengukuran dalam bentuk kuisioner yang berisi 20 pertanyaan mengenai kemampuan seseorang dalam melakukan tugas fungsional yang diukur sebelum dan sesudah diberikan intervensi selama 3 minggu. Pada kelompok I dengan jumlah sampel 15 orang, nilai mean sebelum intervensi $61,75 \pm 5,78$ dan sesudah intervensi $79,83 \pm 4,32$. Pada kelompok II dengan jumlah sampel 15 orang, nilai mean sebeum intervensi $61,16 \pm 7,85$ dan sesudah intervensi $74,83 \pm 9,84$. 
JDP Volume 11, Nomor 3, November 2018: 270-306

\section{B. Hasil Pengukuran Strok Balance Stand Test}

Table 4. Hasil Pengukuran dengan Strok Balance Stand Test Kelompok Perlakuan I

\begin{tabular}{llllll}
\hline Sample & Sebelum & Minggu I & Minggu & Minggu & Selisih \\
\hline 1 & 8 & 11 & 13 & III & \\
2 & 5 & 10 & 20 & 30 & 25 \\
3 & 6 & 9 & 18 & 22 & 16 \\
4 & 4 & 7 & 15 & 20 & 16 \\
5 & 10 & 15 & 19 & 26 & 16 \\
6 & 7 & 7 & 16 & 21 & 14 \\
7 & 5 & 7 & 15 & 20 & 15 \\
8 & 4 & 4 & 10 & 16 & 12 \\
9 & 6 & 9 & 14 & 16 & 10 \\
10 & 4 & 9 & 11 & 20 & 16 \\
11 & 3 & 4 & 13 & 19 & 16 \\
12 & 3 & 10 & 22 & 29 & 26 \\
13 & 2 & 8 & 16 & 19 & 17 \\
14 & 9 & 13 & 19 & 24 & 15 \\
15 & 8 & 9 & 16 & 19 & 11 \\
\hline & & & & & \\
Mean & 5,6 & 8,8 & 15,8 & 21,3333 & 15,7333 \\
& & & & 3 & 3 \\
SD & 2,38447 & 2,93257 & 3,36367 & 4,20317 & 4,54291 \\
\hline & 4 & 6 & 1 & 3 & 7
\end{tabular}


Bisa, Intervensi Mulligan Mobilization with Movementlebih Baik dari semisquat Exercise dalam Meningkatkan Fungsional Sendi Lutut pada Kasus Chondromalacia Patella

Table 5. Hasil Pengukuran dengan Strok Balance Stand Test Kelompok Perlakuan II

\begin{tabular}{|c|c|c|c|c|c|}
\hline Sample & Sebelum & Minggu I & Minggu & Minggu & Selisih \\
\hline & & & II & III & \\
\hline 1 & 4 & 5 & 8 & 15 & 11 \\
\hline 2 & 8 & 9 & 12 & 15 & 7 \\
\hline 3 & 3 & 4 & 6 & 8 & 5 \\
\hline 4 & 2 & 4 & 8 & 11 & 9 \\
\hline 5 & 8 & 9 & 13 & 18 & 10 \\
\hline 6 & 10 & 13 & 16 & 20 & 10 \\
\hline 7 & 4 & 6 & 10 & 15 & 11 \\
\hline 8 & 14 & 14 & 19 & 23 & 9 \\
\hline 9 & 7 & 8 & 15 & 20 & 13 \\
\hline 10 & 8 & 10 & 14 & 17 & 9 \\
\hline 11 & 4 & 5 & 9 & 11 & 7 \\
\hline 12 & 6 & 7 & 12 & 16 & 10 \\
\hline 13 & 10 & 12 & 16 & 21 & 11 \\
\hline 14 & 4 & 6 & 13 & 18 & 14 \\
\hline 15 & 7 & 9 & 12 & 18 & 11 \\
\hline \multirow[t]{2}{*}{ Mean } & 6,6 & 8,06666 & 12,2 & 16,4 & 9,8 \\
\hline & & 7 & & & \\
\hline \multirow[t]{2}{*}{ SD } & 3,22490 & 3,19523 & 3,54964 & 4,08481 & 2,30527 \\
\hline & 3 & 5 & 8 & 5 & 3 \\
\hline
\end{tabular}

Pengukuran strok balance perlakuan I dan II dimana stand test pada kelompok pengukuran dilakukan dalam 
hitungan detik, yang diukur sebelum dan sesudah diberikan intervensi setiap minggu selama 3 minggu. Kelompok perlakuan I dengan jumlah sampel 15 orang, nilai mean sebelum intervensi $5,6 \pm 2,38$ dan sesudah intervensi $21,3 \pm 4,24$. Kelompok perlakuan II dengan jumlah sampel 15 orang, nilai mean sebelum intervensi $6,6 \pm 3,22$ dan sesudah intervensi $16,4 \pm 4,08$.

\section{Uji Persyaratan Analisis}

1. Uji Normalitas dan Homogenitas Data

Uji normalitas pada penelitian ini dilakukan untuk mengetahui apakah data berdistribusi normal atau tidak dari kedua kelompok, dengan menggunakan uji Saphiro Wilk Test, dimana distribusi data dapat dikatakan normal apabila nilai $p>\alpha(0,05)$ dan tidak normal jika nilai $p<$ nilai $\alpha(0,05)$.

a. Uji Normalitas LEFS
Setelah dilakukan uji normalitas (Saphiro Wilk Test) dapat disimpulkan bahwa data terdistribusi secara nomal, dimana pada kelompok perlakuan I sebelum intervensi nilai $p=$ 0,051 , sesudah intervensi nilai $p=0,677$, dan selisih nilai $p=$ 0,103.Pada kelompok perlakuan II sebelum intervensi nilai $p=0,617$, sesudah intervensi nilai $p=$ 0,184 , dan selisih nilai $p=$ 0,634 .

b. Uji Normalitas Strok Balance Stand Test

Setelah dilakukan uji normalitas (Saphiro Wilk Test) dapat disimpulkan bahwa data terdistribusi secara normal, dimana pada kelompok perlakuan I sebelum intervensi nilai $\mathrm{p}=$ 0,640 , sesudah intervensi nilai $p=0,052$, dan selisih nilai $p=$ 0,010 . Pada kelompok perlakuan II sebelum intervensi 0,345 , sesudah 
Bisa, Intervensi Mulligan Mobilization with Movementlebih Baik dari semisquat Exercise dalam Meningkatkan Fungsional Sendi Lutut pada Kasus Chondromalacia Patella

intervensi nilai $p=0,505$, dan selisih nilai $p=0,725$.

\section{Uji Homogenitas}

Uji homogenitas pada penelitian ini dilakukan untuk mengetahui apakah kedua kelompok data yang dianalisis memiliki varian yang sama (homogen) atau berbeda (tidak homogen), maka peneliti melakukan uji homogenitas pada kelompok perlakuan I dan kelompok perlakuan II dengan menggunakan uji Lavene's test, dimana varian data dikatakan homegen apabila nilai $p>$ nilai $\alpha$ $(0,05)$ dan varian data di katakan tidak homogen apabila nilai $p<$ nilai $\alpha(0,05)$. Setelah dilakukan uji homogenitas (Lavene's test) dapat disimpulkan bahwa varian data homogen. Data hasil uji normalitas dan homogenitas dapat dilihat pada Table 6:

Table 6. Hasil Uji Normalitas dan Homogenitas Data Pengukuran LEFS

\begin{tabular}{ccccccc} 
& \multicolumn{3}{c}{ Saphiro Wilk Test } & \multicolumn{3}{c}{ Lavene's Test } \\
\cline { 2 - 7 } Variabel & \multicolumn{2}{c}{$\mathrm{P}$} & $\mathrm{P}$ & \\
\cline { 3 - 7 } & Kelompok I & Ket. & Kelompok II & Ket. & Ket. & \\
\hline Sebelum & 0,051 & Normal & 0,617 & Normal & 0,383
\end{tabular}
Homogen

\begin{tabular}{llccc} 
Sesudah & 0,677 & Normal & 0,184 & Normal \\
Selisi & 0.103 & Normal & 0,634 & Normal \\
\hline
\end{tabular}

Table 7. Hasil Uji Normalitas dan Homogenitas Data Pengukuran

\section{Strok Balance}

\begin{tabular}{clll} 
& \multicolumn{2}{l}{ Saphiro Wilk Test } \\
\cline { 2 - 4 } Variabel & \multicolumn{2}{c}{$\mathrm{P}$} \\
\cline { 2 - 5 } Kelompok I Ket. Kelompok II & Ket. Ket.
\end{tabular}




$\begin{array}{llll}\text { Sebelum } & 0,640 \text { Normal } & 0,345 \text { Normal } 0,313 \text { Homogen } \\ \text { Sesudah } & 0,052 \text { Normal } & 0,505 \quad \text { Normal }\end{array}$

Selisi 0.010 Normal 0,725 Normal

\section{Pengujian Hipotesis}

Table 8. Nilai Lower Extremity Functional Scale Uji Hipotesis I dan II

\begin{tabular}{lccc}
\hline Variabel & Sebelum & Sesudah & Nilai P \\
\hline $\begin{array}{c}\text { Perlakuan I } \\
0.000\end{array}$ & $61,75 \pm 5,78$ & $79,83 \pm, 4,32$ & \\
Perlakuan II & $61,16 \pm 7,85$ & $74,83 \pm 9,84$ & 0.001 \\
\hline
\end{tabular}

Nilai Strok Balance Stand Test Uji Hipotesis I dan II

\begin{tabular}{lccc}
\hline Variabel & Sebelum & Sesudah & Nilai P \\
\hline Perlakuan I & $5,6 \pm 2,38$ & $21,3 \pm 4,24$ & \\
0.000 & & & \\
Perlakuan II & $6,6 \pm 3,22$ & $16,6 \pm 3,94$ & 0.001 \\
\hline
\end{tabular}

Berdasarkan hasil uji Wilcoxon Signed Ranks Test dari data tersebut didapatkan nilai $p<0,001$ pada LEFS perlakuan $\mathrm{I}$, dan $\mathrm{p}=0,001$ pada LEFS kelompok perlakuan II. Sedangkan pada strok blance stand test perlakuan I nilai $p<0,001$ dan pada kelompok perlakuan II $p=0,001$ dimana nilai $p<$ nilai $\alpha(0,05)$ hal ini maka Ho ditolak. Sehingga dapat disimpulkan bahwa pemberian kombinasi Mulligant Mobilization With Movementdan ultrasound dengan kombinasi semi squat exercise dan ultrasound dapat meningkatkan fungsional lutut pada kasus chondromalacia patella.

Untuk menguji signifikasi dua sampel yang saling berpasangan pada kelompok perlakuan I dan kelompok perlakuan II, dengan data berdistribusi normal maka digunaka uji non parametrik yaitu Mann-Whitney 
Bisa, Intervensi Mulligan Mobilization with Movementlebih Baik dari semisquat Exercise dalam Meningkatkan Fungsional Sendi Lutut pada Kasus Chondromalacia Patella

U Test. Dengan ketentuan hasil pengujian hipotesa Ho diterima bila nilai $\mathrm{p}$ $>$ nilai $\alpha(0,05)$ dan Ho ditolak bila nilai $p<$ nilai $\alpha(0,05)$.

Table 9. Nilai LEFS Uji Hipotesis III

\begin{tabular}{lll}
\hline Variabel & Mean & Nilai P \\
\hline Selisi I & $18,03 \pm 4,55$ & 0,023 \\
Selisi II & $13,66 \pm 5,87$ & \\
\hline
\end{tabular}

Nilai Strok Balance Stand Test Uji Hipotesis III

\begin{tabular}{lll}
\hline Variabel & Mean & Nilai P \\
\hline Selisi I & $15,73 \pm 4,54$ & 0,000 \\
Selisi II & $9,73 \pm 2,18$ & \\
\hline
\end{tabular}

Berdasarkan

hasil

Independent Sample $t$-Test dari data tersebut di dapatkan nilai $p=$ 0,023 sedangkan nilai pada Strok Blance Stand Test $\mathrm{p}=0,000$ dimana nilai $p<$ nilai $\alpha(0,05)$, hal ini berarti Ho ditolak. Sehingga dapat disimpulkan bahwa ada perbedaan yang signifikan intervensi kombinasi Mulligan Mobilization With Movement dan ultrasound dengan kombinasi Semi squat exercise dan ultrasound terhadap peningkatan fungsional lutut pada kasus chondromalacia patella.
Kelompok perlakuan I terdiri dari 15 sampel berusia 18-21 tahun (33,33\%), 22-25 tahun $(53,33 \%)$ dan $26-30$ (13,33\%). Sedangkan pada kelompok perlakuan II terdiri dari 15 sampel berusis 18-21 tahun (40\%), 22-25 tahun $(60 \%)$, $26-30$ tahun (0\%). Populasi berdasarkan usia yang rentan terkena kasus patella femoralp pain syndrome (PFPS) adalah usia 18-35 tahun (Zemadenis et al, 2015).

Dalam penggukuran LEFS, terlihat adanya efek peningkatan fungsional lutut yang dapat dilihat dari mean LEFS, pada kelompok 
perlakuan I didapatkan nilai mean sebelum perlakuan $61,75 \pm 5,78$ dan nilai mean sesudah perlakuan $79,83 \pm 4,32$. Berdasarkan hasil uji Wilcoxon Signed Rank Test di dapatkan nilai $p<0,001$ dimana nilai $p<$ nilai $\alpha(0,05)$ sedangkan dalam pengukuran strok balance stand test, terlihat adanya peningkatan fungsional lutut yang dapat dilihat dari nilai mean, pada kelompok perlakuan I didapatkan nilai mean sebelum perlakuan $5,6 \pm 2,38$ dan nilai mean sesudah perlakuan

$21,33 \pm 4,20$.

Berdasarkan hasil uji Wilcoxon Signed Rank Test didapatkan nilai $p<0,001$ dimana nilai $p<$ nilai $\alpha$ $(0,05)$. Hal ini berarti Ho ditolak dan $\mathrm{Ha}$ diterima sehingga dapat disimpulkan bahwa Mulligant Mobilization With Movement dan ultrasound dapat meningkatkan fungsional lutut pada kasus chondromalacia patella. Menurut penelitian sebelumnya memberikan kesimpulan bahwa mulligan mobilization with movement menunjukkan peningkatan nilai LEFS setelah diberikan intervensi meningkat secara signifikan dibandingkan dengan sebelum diberikan intervensi mulligan mobilization with movement (Zemadanis Konstantinos et al, 2015).

Pada kelompok perlakuan I terdapat sampel yang mengalami peningkatan fungsional lutut lebih besar sebelum dan sesudah perlakuan dengan selish sebesar 26 detik untuk strok balance stand test dan 23,75 untuk LEFS yaitu pada sampel nomor 12 dan terdapat sample yang peningkatannya hanya sedikit yaitu sampel nomor 9. Sebelum diberikan perlakuan, nilai strok balance stand test pada sample nomor 12 yaitu pada skala 3 detik. Nilai katagori poor $<10$ dan nilai katagori excellent $>50$ sedangkan nilai LEFSnya $63,75 \%$ nilai maksimum $100 \%$. Setelah diberikan perlakuan berupa MWM dan US selama 3 minggu terjadi peningkatan sebesar 26 detik, sehingga nilainya menjadi 29 detik 
Bisa, Intervensi Mulligan Mobilization with Movementlebih Baik dari semisquat Exercise dalam Meningkatkan Fungsional Sendi Lutut pada Kasus Chondromalacia Patella

yang masuk ke katagori average sedangkan nilai LEFS terjadi peningkatan 23,75\%, sehingga nilainya menjadi $87,5 \%$. Namun sampel nomor 12 masih membutuhkan latihan lebih lanjut. Peningkatan fungsional lutut pada sampel nomor 12 dapat di capai karena faktor semangat yang tinggi dari sampel untuk meningkatkan fungsional lututnya dan menghindari gerakan-gerakan yg menjadi kontra indikasi selama program terapi.

Peningkatan fungsional lutut paling rendah terjadi pada sampel nomor 9 berjenis kelamin perempuan berusia 21 tahun dan sebagai mahasiswa. Faktor yang menyebabkan sedikitnya peningkatan fungsional lutut adalah kurangnya kesadaran sampel ketika melakukan kegiatan sehari-hari dengan tetap menggunakan tangga ketika dikampus dan banyak melakukan aktivitas berjalan.

Pada pemberian intrevensi semi squat exercise dan ultrasound. terlihat adanya peningkatan fungsional lutut yang dilihat dari mean LEFS. Pada kelompok perlakuan II didapatkan nilai mean sebelum perlakuan $61,16 \pm 7,85$ dan sesudah perlakuan $74,83 \pm 9,84$. Berdasarkan hasil uji Wilcoxon Signed Rank Test didapatkan nilai $p=0,001$ dimana nilai $p<$ nilai $\alpha(0,05)$ sedangkan dalam pengukuran fungsional lutut menggunakan strok balance stand test, terlihat adanya peningkatan fungsional lutut yang dilihat dari mean strok blance stand test, pada kelompok perlakuan II didapatkan nilai mean sebelum perlakuan $6,6 \pm 3,22$ dan sesudah perlakuan $16,4 \pm 4,08$. Berdasarkan hasil uji Wilcoxon Signed Rank Test didapatkan nilai $p=0,001$ dimana nilai $p<$ nilai $(0,05)$. Hal ini berarti Ho ditolak dan $\mathrm{Ha}$ diterima sehingga dapat disimpulkan bahwa semi squat exercise dan ultrasound efektif terhadap peningkatan fungsional lutut pada kasus chondromalacia patella. 
Hasil penelitian ini menguatkan jurnal dengan judul "Open versus closed kinetic chain exercises for patellar chondromalacia" memberikan kesimpulan bahwa hasil penelitian ini menunjukkan semi squat exercise (closed kinetik chain) lebih efektif dibandingkan dengan straight leg raise (open kinetik chain). Menurut jurnal dengan judul "Therapeutic ultrasound for treating patellofemoral pain syndrome" memberikan kesimpulan bahwa ultrasound efektif dalam meningkatkan kelenturan collagen dan tendon dengan meningkatnya suhu.

Pada kelompok perlakuan II terdapat sampel yang mengalami peningkatan fungsional lutut lebih besar sebelum dan sesudah perlakuan dengan selisih sebesar 22 detik untuk strok balance stand test dan 26,25\% untuk LEFS yaitu pada sampel nomor 14 dan terdapat sampel yang peningkatannya kurang yaitu sampel nomor 3 . Sebelum diberikan perlakuan, nilai strok balance stand test pada sampel nomor 14 yaitu pada skala 4 detik. Nilai katagori poor $<10$ dan nilai katagori excellent $>50$ sedangkan nilai LEFSnya $60 \%$ dari nilai maksimum $100 \%$ Setelah diberikan perlakuan berupa semi squat exercise dan US selama 3 minggu terjadi peningkatan sebesar 22 detik, sehingga nilainya menjadi 26 detik yang masuk ke katagori average sedangkan nilai LEFS terjadi peningkatan $26,25 \%$ sehingga nilainya menjadi $86,25 \%$. Peningkatan fungsional lutut paling rendah terjadi pada sampel nomor 3 berjenis kelamin perempuan. Penerapan semi squat exercise merupakan latihan yang bersifat closed kinetik chain exercise, latihan ini dapat menguatkan otot ektremitas bawah dengan meminimalkan stres pada ligamen anterior dengan mengurangi gaya geser pada sendi lutut melalui pengurangan gaya tekan pada saat kontraksi (Tae-Sik lee et al, 2016). 
Bisa, Intervensi Mulligan Mobilization with Movementlebih Baik dari semisquat Exercise dalam Meningkatkan Fungsional Sendi Lutut pada Kasus Chondromalacia Patella

Berdasarkan hasil ujiMannWhitney $U$ Test, dengan nilai $\mathrm{p}=$ 0,023 untuk LEFS dimana nilai $p<$ nilai $\alpha(0,05)$. Sedangkan nilai strok balance stand test didapatkan nilai $\mathrm{p}=0,000$ dimana nilai $\mathrm{p}<$ nilai $\alpha$ $(0,05)$ sehingga dapat disimpulkan bahwa ada perbedaan efek intervensi Mulligan Mobilization With Movement dan ultrasound dengan semi squat exercise dan ultrasound dalam peningkatan fungsional lutut pada kasus chondromalacia patella. Penerapan konsep Mulligan tidak ada rasa sakit/nyeri yang ditimbulkan selama dan setelah aplikasi dilakukan. Keberhasilan dari teknik ini ditandai dengan tidak ditemukan rasa sakit/nyeri selama fisioterapis melakukan intervensi dalam menggerakkan dan meningkatkan fungsi.

\section{KESIMPULAN DAN SARAN}

\section{a. Kesimpulan}

1. Kombinasi Mulligan Mobilizatiom With Movement dan ultrasound dapat meningkatkan fungsional lutut pada kasus chondromalacia patella.

2. Kombinasi semi squat exercise dan ultrasound dapat meningkatkan fungsional lutut pada kasus chondromalacia patella.

3. Ada perbedaan antara kombinasi Mulligan Mobilization With Movement dan ultrasound dengan semi squat exercise dan ultrasound dalam meningkatkan fungsional lutut pada kasus chondromalacia patella.

\section{b. Saran}

1. Agar sample dipilih berdasarkan kesamaan aktivitas dan pekerjaan.

2. Aktifitas sample selama proses penelitian agar dibatasi untuk tercapainya hasil intervensi yang lebih baik.

\section{ACUAN PUSTAKA}

Adalberto LS, Julie. R, Karen A.B, Camen. O, Jhonathan. D. A, Norma. J.M. 2012. Effect of 
Low-Intensity Pulsed Ultrasound on The Cartilage Repair in People With Mild to Moderate Kneee Osteoarthritis: A DoubleBlinded, Randomized, Placebo Controlled Pilot Study. American Congress of Rehabilitation Medicine, 2012. Volume 93. Issue 1, Pages 35-42.

Bakhtiary A H, Fatemi E. 2007. Open versus closed kinetic cahain exercise for patellar chondromalacia.

Physiotherapy Department, Rehabilitation faculty, Semnan, University of Medical Sciences, Iran.

Binkley JM, et al. 1999. The Lower Extremity Functional Scale (LEFS): Scale development, measurement properties, and clinical aplication. North American Orthopedic Rehabilitation Research Network.

Brosseau L, et al. 2009. Therapeutic untrasound for treating patellofemoral pain syndrome (review). Faculty of Health Sciences, University of Ottawa. Canada.

Cook and Hegedus, 2013. Orthopedic Examination Test an Evidence-Based Approach, 2
Edition, New Jersey : Pearson Education In.

Crossley K, Bennell K., Green S., McConnel J. 2001, A systematic review of physical interventions for patellofemoral pain syndrome, Clin J Sport Med ;11:103-10.

Dawid Bączkowicz, Edyta Majorczyk. 2016. Joint Motion Quality in Chondromalacia Progression Assessed by Vibroacoutic Signal Analysis. Institute of Physiotherapy, Faculty of Physical Education and Physiotherapy, Opole University of Technology, Opole, Poland.

Fernando Ruiz Santiagoa, et al. 2014. T2 Mapping in Patellar Chondromalacia. European Journal of Radiology, Spain.

Johnson BL, Nelson JK. 1979. Practical measurements for evaluation in physical education. 4th Edit. Minneapolis: Burgess.

Kisner C. Colby L, A. 2012. Therapeutic Exercise: Fondation and techniques 6 th edition. Philadelphia. F A Davis Company. United States of America.

Lankhrost E. Nienke., BiermaZeinstra S.M, Van 
Bisa, Intervensi Mulligan Mobilization with Movementlebih Baik dari semisquat Exercise dalam Meningkatkan Fungsional Sendi Lutut pada Kasus Chondromalacia Patella

Middlekoop M, Risk Factors for Patellofemoral Pain Syndrome: A Systematic Review, Journal of Orthopedic \& Sports Physical Therapy, 2012; volume 42, number $2,81$.

Mulligant Brian R. 2004. Ebook; Manual Therapy "NAGs", "SNAGs", "MWMs"., 5Th Edn. New Zealand.

Netter FH, 2003. Atlas of Human Anatomy. Philadelpia.

Pocock. 2008.Clinical Trials A Practical Approach. A Willey Medical Publication : New York.

Sugijanto. 2012. Anatomi Terapan dan Biomekanik Lutut.

Lee TS, Song MY, Kwon YJ. 2016. Activation of Back and Lower Limb Muscles During Squat Exercise With Different Trunk Flexion. Busan. Republic of Korea.

Doi:

10.1589/jpts.28.3407.
Waryasz Gregory R, McDermott Ann Y. 2008. Patellofemoral pain syndrome (PFPS): a systematic review of anatomy and potential risk factors.

USA.Doi:10.1186/14765918-7-9.

World Health Organization, Programmes and Projects: International Classification of Functioning, Disability and Health (ICF), 2001, available at

http://apps.who.int/classificati ons/icfbrowser/ , accessed 24 maret 2017.

Zemadanis Konstantinos, et al. 2015. Mobilization-withmovement prior to exercise provides eary pain and functionality improvements in patients with patellofemoral pain syndrome. International Musculoskeletal Medicine, 37:3, 101-107. 